\title{
The Threats of Unsystematic Risks in Jordanian Commercial Banking Sector
}

\author{
Ghaith N. Al-Eitan ${ }^{1} \&$ Ismail Y. Yamin ${ }^{2}$ \\ ${ }^{1}$ Financial Assistant Professor, Faculty of Economics and Administrative Sciences, Al Albayt University, Jordan \\ ${ }^{2}$ Finance Associate Professor, Faculty of Economics, Zarqa University, Jordan \\ Correspondence: Ghaith N. Al-Eitan, Financial Assistant Professor, Faculty of Economics and Administrative \\ Sciences, Al albayt University, Jordan. E-mail: ghaith.eitan@aabu.edu.jo
}

Received: July 11, 2017

Accepted: August 23, 2017

Online Published: August 25, 2017

doi:10.5539/ijef.v9n9p175

URL: https://doi.org/10.5539/ijef.v9n9p175

\begin{abstract}
The objective of this study is to empirically examine the effect of unsystematic risks on the performance of commercial banks in Jordan, using panel data for the period of 10 years (2005-2015). The study uses earning per share and dividends as dependent variables to represent Banks' performance. The empirical analysis based on the fixed effect model selected on the basis of Hausman test. The results indicate that the impact of Non-performing loans on commercial banks' dividends is positive and significant while the impact of capital adequacy is negative and statistically significant on dividends. The results indicate that the credit risk, liquidity risk, non-performing loan and capital adequacy have significant effect on earnings per share and the effects are negative as expected. Based on the study it is recommended that the Jordanian commercial banks needs enhance the process of credit risk management to determine loan defaulter and impose the appropriate legal action against them.
\end{abstract}

Keywords: earning per share, dividends, credit risk, liquidity risk, non-performing loan, capital adequacy

\section{Introduction}

Banks and financial institutions are an important sector in constructing the country national economy. Banking sector has a large role that cannot be ignored in the process of economic development, as it is the tool through which the state implements its monetary system and its financial policy and gives the banking sector a key indicator on the vitality of the economic situation in the country. The role of banks in the business sector is clearly manifested by the provision of a variety of banking services, which greatly help in stimulating economic, financial and commercial operations, with the increasing interconnection between banks at the international level through large volumes of for transactions between them.

Banks are considered the main component of the financial sector in Jordan as the banking system constitutes $94 \%$ of the size of the financial sector. Jordan has a sound and solid banking system is able to generally withstand the shocks and high risks as a result of the banks in Jordan at high levels of Money is the highest in the Middle East and North Africa region. These banks enjoy comfortable levels of liquidity and profitability. There has been a marked improvement in most of the financial ratios and indicators of banks such as non-performing debt ratio, coverage ratio for non-performing debt, Money and liquidity ratios and profitability (Central Bank of Jordan Report, 2016).

The banking system in Jordan is generally able to withstand the high shocks and risks as well as improve the ability of banks to face these risks according to 2015 performance results compared to the performance results in 2014. This is due to the high profits of banks in 2015 and the high levels of capital, which is considered one of highest in the Middle East and North Africa (Central Bank of Jordan Report, 2016).

The banks face a number of risks that obstruct the good conduct of their activities. Most of these risks are due to the internal and external environment of the banks and due to the changes of the latter, there are problems and difficulties in the adjustment which explains the banks' risk of carrying out their activities. Mainly due to the effectiveness of the control systems, which are specially designed to cope with the changes and imbalances that may occur in the surrounding environment banks.

In recent years, interest has increased in terms of the risks associated with the banks' business because of their significant impact on the returns they make, their survival and continuity, as well as their impact on the national economy, especially in developing countries. In addition to the regulatory requirements of the local supervisory 
authorities, by the international supervisory bodies such as the Basel Committee of the Bank of International Settlements as well as the banks themselves focused on the risks face and how to measure and impact in their operations, which highlighted the role of these banks in the development of policies to determine the appropriate level of risk.

This study has identified some of the unsystematic risks variables and the importance of each variable and determined the degree of the impact of each variable on the performance of Jordanian commercial banks.Thus; this study aimed to analyze and measure the impact of unsystematic risks variables on the performance of commercial banks in Jordan.

The paper is organized as followings: Section 2 discusses related literature on the effects of unsystematic risks on the performance of commercial banks. The research methods and its design are described in section 3 . Section 4 shows the results and discussion. Finally, the last section draws the conclusions.

\section{Literature Review}

Credit riskis the potential that a counter party cannot pay off its liabilities on agreed terms. It has a strong connection with the profitability of commercial banks and economic growth. Thus, it is important risk exposure for commercial banks as it works with depositors' money. The efficient uses of available credit means that lower credit risk and higher return on investment. Each loan without repayment reduces commercial banks' return and equity. This may result in bank failure if the bank cannot meet its obligations. The impact of credit risk on the profitability of commercial banks has been investigated in terms of the lending (Boivin et al., 2010). There has been extensive growing research into the credit risk after the Global Financial Crisis (GFC) (Gilchrist et al., 2009; Ciccarelli et al., 2010; Hempell \& Kok, 2010; Alper \& Anbar, 2011; Dang, 2011; Gilchrist \& Mojon, 2014).

Most of the studies use panel data or time series to examine the effect of credit risk on the bank performance. The researchers, generally, use return on assets and return on equity to measure the bank performance. Also, they employ loan loss provisions, default spreads and non-performing loans as credit risk indicators in their research papers (Pasiouras \& Kosmidou, 2007; Mileris, 2012; Romanova, 2012). They conclude that higher credit risk contributes in decreasing the profitability of banks.

Several researchers analyze the effects of non-performing loans on the performance of banking sectors (Mohammad, 2008; Waweru \& Kalani, 2009; Mileris, 2012). Their findings prove that non- performing loans do affect commercial banks. There are many researchers examine the effects of non-performing loans on the banks performance in African region for example: (Kaaya \& Pastory, 2013; Ogboi \& Unuafe, 2013; Iwedi \& Onuegbu, 2014). Kaaya and Pastory (2013) employ panel data analysis to examine the performance of Tanzanian commercial banks over the period (2005-2011). The study finds that negative correlation between non-performing loans and bank performance. Ogboi and Unuafe (2013) also employ panel data analysis to examine the effect of credit risk management represented by capital adequacy on Nigerian banks performance over the period (2004-2009). The result indicates that sound credit risk management influence bank financial performance positively. In an attempt to, Iwedi and Onuegbu (2014) use panel data of 5 Nigerian DMBs to examine the effect of credit risk management on bank performance. The results show that a positive effects of non-performing loans on bank performance.

Chen et al. (2010) examine the effect of liquidity risk of bank and its performance using panel data for commercial banks in 12 over years 1994-2006. They find that liquidity risk is the endogenous determinant of bank performance. Alper and Anbar (2011) find that bank's size and liquidity have positive effect on the turkey's banks profitability, but credit risk and loans have a negative effect on the bank's performance. Tabari et al. (2013) examine the effect of liquidity risk on the performance of commercial banks using of panel data related to commercial banks of Iran during the years 2003 to 2010. The results show that the bank's size positively improve the performance of banks while credit risk and liquidity risk negatively affect the performance of bank.

\section{Data and Research Methodology}

The primary source of data for this research is Amman Stock Exchange (ASE) and annual reports of Jordanian commercial banks. The research period covers the years 2005-2015. The sample includes 13 commercial banks in Jordan. The main objective of this research is to examine the impact of various unsystematic risks including: credit risk, liquidity risk, non-performing loans and capital adequacy on the earning per share and dividends. The research uses the size of commercial banks as a control variable.

Stationary test for time series to test the stability of time series or not to contain the root of the unit. Time series data stability test (root unit): On the application level, there are several tests that can be used to test the stability of the series. The unit root tests will be focused on the most practical tests. As the root of the unit is based on an 
intrinsic correlation between errors, on the premise that the limits of error are not intrinsically correlated and dropping this hypothesis leads to the problem of self-association.

The Augmented Dickey-Fuller (1981) test is one of the most commonly used tests in practical applications, and the content of this test. If the regression coefficient of the proposed standard formula is equal to one, this causes a unit root problem which means the instability of time series data $(p=1)$ The Augmented Dickey-Fuller test is based on the assumption that the error limit is a white nuisance, that is, he did not take into account the possibility of self-correlation and this is the weakness of the test, so it was modified with the compound or modified the Augmented Dickey-Fuller test.

Phillips and Perron (1988), this test is based on the introduction of a self-correlation correction using a non-parameterized method. What distinguishes this test is that it takes into account the structural changes of the time series. It has a greater test power than the ADF test, as it differs from DF and ADF in that it contains slower values of differences Takes into account the first differences in the time series using Non-Parametric Correlated and allows an average of zero and a linear trend of time that is not based on the distribution of the error limit coefficient.

The term of panel data is time series data and cross-sectional data. In this context, panel data is generally an analysis of extended data (Hsiao, 1986). The advantage of using panel data is that it takes into account individual differences and gives more useful and varied data and less correlation between variables and a large number of degrees of freedom and more efficient than time series that suffer from the problem of self-correlation. The panel data also have the ability to define and measure non-observed effects in descriptive analysis and time series analysis (Baltagi, 2000).

$$
Y_{i t}=\beta X_{i t}+U_{i t}
$$

Where $Y$ represents the dependent variable $i$ represents the unit $X$ donates the independent variables $U$ donates the unspecified error limit structure in this equation where it appears independent of each units $t$ is time (Worral \& Pratt, 2004).

In the analysis of panel data, it is possible to use the fixed effects model or random effects model. The fixed effects model has constant trends over time. The fixed limit is different for each unit, but it is constant over time. The fixed limit reflects the characteristics of the units under test, as these characteristics vary from unit to unit. For the random effects model, the slope is also constant over time, but the random limit is random. This randomization is a function of the average values plus the random limit (Brooks, 2008; Verbeek, 2012).

$$
Y_{i t}=\alpha+\beta X_{i t}+U_{i}+V_{i t}
$$

The Hausmann test has been used to select the appropriate model (fixed effects model or random effects model), depending on the probability value of Chi-Square. If the value is less than $5 \%$, the fixed effects model is used. If the value greater than $5 \%$, the random effects model is used (Torres-Reyna, 2007).

$$
Y_{i t}=\alpha+\beta X_{i t}+\hat{\gamma}_{x_{i t}}+u_{i t}
$$

This research attempts to examine the impact of Jordanian commercial banks risks on its earnings per share and dividends over the period of 2005-2015. Thus, the research employs the following empirical model:

$$
Y_{i t}=\alpha_{i}+\beta_{1} C R_{i t}+\beta_{2} L R_{i t}+\beta_{3} N P L_{i t}+\beta_{4} C A_{i t}+\beta_{5} s z_{\text {control }}+U_{i t}
$$

Where, $Y_{i t}$ represents the dependents variables including: earning per share and dividends, $t$ represents bank, $i$ represents time, $\alpha_{\mathrm{i}}$ represents the individual effect of each bank, $C R$ is credit risk, $L R$ is liquidity risk, $N P L$ is non-performing loan, $C A$ is capital adequacy, $S Z$ is the size of bank in logarithm and $U$ is the error terms.

\section{Empirical Results}

Descriptive statistics of both dependent and explanatory variables can be found in Table 1. Comparing the earnings per share and dividends of the commercial banks. The averages of all risks are higher for the commercial banks, regardless of whether they are anticipated to have a positive or negative effect on earnings per share and dividends. 
Table 1. Descriptive statistics of research variables

\begin{tabular}{lccccccc}
\hline Descriptive Analysis & EPS & DV & CR & LR & NPL & CA & SZ \\
\hline Mean & 0.411818 & 0.270909 & 74.99 & 38.74545 & 6.67 & 0.18326 & $3.45 \mathrm{E}+09$ \\
Median & 0.38 & 0.25 & 75.28 & 38.57 & 7.35 & 0.190376 & $1.23 \mathrm{E}+09$ \\
Maximum & 0.72 & 0.35 & 79.87 & 44.11 & 11.81 & 0.204 & $2.59 \mathrm{E}+10$ \\
Minimum & 0.24 & 0.2 & 64.7 & 35.77 & 2.19 & 0.151936 & $1.17 \mathrm{E}+08$ \\
Std. Dev. & 0.118337 & 0.040244 & 3.888655 & 2.590604 & 3.055097 & 0.017189 & $5.99 \mathrm{E}+09$ \\
\hline
\end{tabular}

That might be an indication of the commercial banks expanding in terms of business activity. However, the standard deviation is in all cases higher for the credit risk, non-performing loans and liquidity risk indicating higher distribution.

Table 2. Cross-correlation matrix of explanatory variables for commercial banks

\begin{tabular}{lccccccc}
\hline Correlation & EPS & DV & CR & LR & NPL & CA & SZ \\
\hline EPS & 1 & & & & & & \\
DV & 0.143826 & 1 & & & & & \\
CR & -0.11453 & -0.25184 & 1 & & & & \\
LR & 0.092781 & -0.02824 & -0.73184 & 1 & & & \\
NPL & -0.10076 & 0.489728 & -0.46355 & -0.18723 & 1 & & \\
CA & -0.17085 & 0.31334 & -0.56697 & -0.03774 & 0.832691 & 1 & 1 \\
SZ & -0.02373 & -0.01927 & 0.011637 & 0.043946 & -0.06826 & -0.0668 & \\
\hline
\end{tabular}

The correlation matrix is used to show the relationship between independent and dependent variables. Also, it is used to show the relationship among the independent variables to ensure that there is no strong correlation between them, which refers to what is known as serial correlation and multicollinearity issues, which negatively affects the validity of the results. It is noted from the table that the relationship between independent variables, credit risk and liquidity risk strong at -0.73184 , the relationship between credit risk and non-performing loans is weak at -0.46355 . Also, it is noted that the relationships between independent variables and dependent variables are weak.

The fixed effects model, the random effects model, and the Hausmann test are estimated. The Generalized Least Square (GLS) method is used to take into account the lack of homogeneity and self-correlation of error reduction (Green, 2008).

Table 3. Unit root test of explanatory variables for commercial banks

\begin{tabular}{|c|c|c|c|c|}
\hline \multirow[t]{2}{*}{ Variables } & \multicolumn{2}{|c|}{ t- Statistics in Log } & \multirow{2}{*}{$\begin{array}{l}\text { t-statistics in Log First } \\
\text { ADF }\end{array}$} & \multirow{2}{*}{$\begin{array}{c}\text { Differences } \\
\text { PP } \\
\end{array}$} \\
\hline & ADF & PP & & \\
\hline EPS & 18.5302 & $115.925 * * *$ & $53.6976^{* *}$ & $139.094 * * *$ \\
\hline DV & 6.07884 & 6.79716 & $45.4863 * *$ & $59.2244 * *$ \\
\hline CR & 19.0676 & $63.3983^{* *}$ & $61.7943 * * *$ & $249.614 * * *$ \\
\hline LR & 28.2751 & $86.8148 * * *$ & $37.0450^{*}$ & $143.948 * * *$ \\
\hline NPL & 8.39366 & 5.57714 & $43.7146^{* *}$ & $38.3088^{* *}$ \\
\hline CA & 24.2939 & 8.72896 & $67.7788 * * *$ & $117.287 * * *$ \\
\hline SZ & 28.3267 & 26.1338 & $60.4539 * * *$ & $105.760 * * *$ \\
\hline
\end{tabular}

Note. $* * *$ indicate statistical significant at $1 \%$ level; ** indicate statistical significant at $5 \%$ level; * indicate statistical significant at $10 \%$ level.

The results indicate that the null hypothesis of both tests cannot be rejected when all variables are in levels series. In other words, the variables in levels are non-stationary, as the value of the $(t)$ statistic is greater than the critical values of the ADF and PP test. The data are transformed from levels to first difference test again, for stationary and non-stationary time series data. The results indicate that the acceptance of the alternative hypothesis at $\% 1$ level as the $(t)$ statistic is smaller than the critical values of the ADF and PP tests.

Table 4. Regression estimate for commercial banks, dividends as dependent variable (fixed effects model and 
random effects model)

\begin{tabular}{|c|c|c|}
\hline \multirow[t]{3}{*}{ Independent Variables } & \multicolumn{2}{|c|}{ Dependent Variables } \\
\hline & DV & DV \\
\hline & Fixed effects model & Random effects model \\
\hline \multirow{3}{*}{$\mathrm{CR}$} & 0.000109 & 0.000113 \\
\hline & $(0.036180)$ & $(0.037690)$ \\
\hline & 0.001809 & 0.001821 \\
\hline \multirow[t]{2}{*}{ LR } & $(0.466601)$ & $(0.469929)$ \\
\hline & 0.010616 & 0.010615 \\
\hline \multirow[t]{2}{*}{ NPL } & $(4.438139)^{* * *}$ & $(4.437730)^{* * *}$ \\
\hline & -0.810314 & -0.811287 \\
\hline \multirow[t]{2}{*}{ CA } & $(-2.139232)^{* *}$ & $(-2.142295)^{*}$ \\
\hline & $1.25 \mathrm{E}-13$ & $4.91 \mathrm{E}-14$ \\
\hline $\mathrm{SZ}$ & $(0.153434)$ & $(0.095946)$ \\
\hline Adjusted R-squared & 0.579919 & 0.569836 \\
\hline F-statistic & $2.858323^{* * *}$ & $10.64689^{* * *}$ \\
\hline Hausman test Chi-Sq & 5 & \\
\hline Prob $($ Chi-Sq) & 1.000 & \\
\hline NO & 143 & 143 \\
\hline Banks & 13 & 13 \\
\hline
\end{tabular}

Note. ${ }^{*}, * *$ and $* * *$ represent statistical significance at the $1 \%, 5 \%$ and $10 \%$ levels respectively.

The results of the Hausman test indicate that the fixed effects model is appropriate to test the impact of various unsystematic risks including: credit risk, liquidity risk, non-performing loans and capital adequacy on the earning per share and dividends, where the probability or moral level is less than $5 \%$ the probability for the Chi-Square is less than 5\%).

The model, with DV as the dependent variable, is estimated using the fixed-effects model, in accordance with the results of the Hausman test. Non-performing loans has positive significant effect at the $1 \%$ level. The results indicate that the capital adequacy has negative significant effect at the $1 \%$ level on the dividends. Therefore, the model seems to capture the changes in DV relatively well with highest value of an adjusted $\mathrm{R}^{2}$ of 0.579 .

Table 5. Regression estimate for commercial banks, earning per share as dependent variable (fixed effects model and random effects model)

\begin{tabular}{|c|c|c|}
\hline \multirow[t]{3}{*}{ Independent Variables } & \multicolumn{2}{|c|}{ Dependent Variables } \\
\hline & EPS & EPS \\
\hline & Fixed effects model & Random effects model \\
\hline \multirow{3}{*}{$\mathrm{CR}$} & -0.055621 & -0.055681 \\
\hline & $(-6.289076)^{* * *}$ & $(-6.296360)^{* * *}$ \\
\hline & -0.062522 & -0.062685 \\
\hline \multirow[t]{2}{*}{ LR } & $(-5.480689)^{* * * *}$ & $(-5.496857)^{* * *}$ \\
\hline & -0.019854 & -0.019840 \\
\hline \multirow[t]{2}{*}{ NPL } & $(-2.821227)^{* * *}$ & $(-2.819270)^{* * *}$ \\
\hline & -5.766203 & -5.753306 \\
\hline \multirow[t]{2}{*}{$\mathrm{CA}$} & $(-5.174008) * * *$ & $(-5.163625)^{* * *}$ \\
\hline & $-1.66 \mathrm{E}-12$ & $-6.50 \mathrm{E}-13$ \\
\hline $\mathrm{SZ}$ & $(-0.690983)$ & $(-0.432091)^{* * *}$ \\
\hline Adjusted R-squared & 0.579094 & \\
\hline F-statistic & $2.846646^{* * *}$ & \\
\hline Hausman test Chi-Sq & 5 & \\
\hline Prob $($ Chi-Sq) & 1.000 & \\
\hline NO & 143 & 143 \\
\hline Banks & 13 & 13 \\
\hline
\end{tabular}

Note. ${ }^{*}, * *$ and $* * *$ represent statistical significance at the $1 \%, 5 \%$ and $10 \%$ levels respectively. 
The model, with EPS as the dependent variable, is estimated using the fixed-effects model, in accordance with the results of the Hausman test. Table 3 show that the results of the fixed effects model. The results indicate that the credit risk has significant effect at the $1 \%$ level on earning per share and the effects are negative as expected. Also, the results of fixed effects model show that the liquidity risk has significant effect at the $1 \%$ level on earning per share and the effects are negative as expected. Non-performing loans has a negative effect at the $1 \%$ level of significance. The results indicate that the capital adequacy has negative significant effect at the $1 \%$ level on the earning per share. Therefore, the model seems to capture the changes in DV relatively well with highest value of an adjusted $R^{2}$ of 0.579 .

\section{Conclusion}

The study investigates the effects of unsystematic risks on the performance of Jordanian commercial banks. The study period covers the years 2005-2015. The sample includes 13 commercial banks in Jordan. The main objective of this research is to examine the impact of various unsystematic risks including: credit risk, liquidity risk, non-performing loans and capital adequacy on the earning per share and dividends. Based on the empirical analysis of fixed effects model using a panel data, the study finds that there are several variables that appear to be the most significant ones when it comes to evaluating the performance of commercial banks. The results indicate that the impact of Non-performing loans on commercial banks' dividends is positive and significant while the impact of capital adequacy is negative and statistically significant on dividends. The results indicate that the credit risk, liquidity risk, non-performing loan and capital adequacy have significant effect on earnings per share and the effects are negative as expected. Based on the study it is recommended that the Jordanian commercial banks needs enhance the process of credit risk management to determine loan defaulter and impose the appropriate legal action against them.

\section{References}

Alper, D., \& Anbar, A. (2011). Bank Specific and Macroeconomic Determinants of Commercial Bank Profitability: Empirical Evidence from Turkey. Business and Economics Research Journal, 2(2), 139-152.

Baltagi, B. H. (2000). Econometric analysis of panel data (2nd ed.). New York: John Wiley \& Sons.

Boivin, J., Kiley, M. T., \& Mishkin, F. M. (2010). How has the Monetary Transmission Mechanism Evolved over Time? NBER Working Papers, 15879.

Brooks, C. (2008). Introductory Econometrics for Finance (2nd ed.). Cambridge, Cambridge University Press. https://doi.org/10.1017/CBO9780511841644

Chen, Y. K., Shen, C. H., \& Kao, L. F. (2010). Bank Liquidity Risk and Performance. Journal of Financial Regulation, 20(2).

Ciccarelli, M., Maddaloni, A., \& Peydro, J. (2010). Trusting the Bankers: A New Look at the Credit Channel of Monetary Policy. European Central Bank Working Paper, 1228.

Dang, U. (2011). The CAMEL Rating System in Banking Supervision: A Case Study Dissertation. Arcada University of Applied Sciences, International Business.

Gilchrist, S., \& Mojon, B. (2014). Credit Risk in the Euro Area. NBER Working Paper, (1). https://doi.org/10.3386/w20041

Gilchrist, S., Vladimir, Y., \& Egon, Z. (2009). Credit market shocks and economic fluctuations: Evidence from corporate bond and stock markets. Journal of Monetary Economics, 56, 471-493. https://doi.org/10.1016/j.jmoneco.2009.03.017

Green, W. H. (2008). Econometric Analysis (7th ed.). Prentice Hall.

Hempell, H., \& Kok, S. C. (2010). The impact of supply constraints on bank lending in the Euro area-crisis induced crunching? European Central Bank Working, 1262.

Hsiao, C. (1986). Analysis of panel data. Cambrige, U.K: Cambridge University Press.

Iwedi, M., \& Onuegbu, O. (2014). Credit Risk and Performance of Selected Deposits Money Banks in Nigeria: An Empirical Investigation. European Journal of Humanities \& Social Sciences, 31(1), 16841694.

Kaaya, I., \& Pastory, D. (2013). Credit Risk and Commercial Banks Performance in Tanzania: A Panel Data Analysis. Research Journal of Finance and Accounting, 4(16), 55-62.

Mileris, R. (2012). Macroeconomic determinants of loan portfolio credit risk in banks. Engineering Economics, 23(5), 496-504. 
Mohammad, M. S. (2008). Non-performing loans in Bangladesh MFI sector: Some issues and observations. Economics and Finance Review, 2(3), 10-15.

Ogboi, C., \& Unuafe, O. K. (2013). Impact of Credit Risk Management and Capital Adequacy on the Financial Performance of Commercial Banks in Nigeria. Journal of Emerging Issues in Economics, Finance \& Banking, 2(3), 703-717.

Pasiouras, F. O., \& Kosmidou, K. (2007). Factors influencing the profitability of domestic and foreign commercial banks in the European union. Research in International Business and Finance, 21(2), 222-237. https://doi.org/10.1016/j.ribaf.2006.03.007

Romanova, I. (2012). Bank lending and crisis: Case of latvia. Journal of Business Management, 5, Special Edition, 87.

Tabari, N. A. Y., Ahmadi, M., \& Emami, M. (2013). The effect of liquidity risk on the performance of commercial banks. International Research Journal of Applied and Basic Sciences, 4(6), 1624-1631.

Torres-Reyna, O. (2007). Panel Data Analysis: Fixed and Random Effects using STAT. Princeton University.

Verbeek, M. (2012). A Guide to Modern Econometrics (4th ed). West Sussex, John Wiley \& Sons Ltd.

Waweru, N. M., \& Kalani, V. M. (2009). Commercial Banking Crises in Kenya: Causes and Remedies. African Journal of Accounting, Economics, Finance and Banking Research, 4(4), 12-33.

Worrall, L. J., \& Pratt, C. T. (2004). Estimation issues associated with time-series-cross-section analysis in criminology. Western Criminology Review, 5(1), 35-49.

\section{Copyrights}

Copyright for this article is retained by the author(s), with first publication rights granted to the journal.

This is an open-access article distributed under the terms and conditions of the Creative Commons Attribution license (http://creativecommons.org/licenses/by/4.0/). 